\title{
Reflections on graduate professor training
}

\author{
Reflexões sobre a formação docente na pós-graduação \\ Reflexiones sobre la formación docente en el postgrado
}

\author{
Larissa Roberta Alves ${ }^{1}$ (1) \\ Márcia Aparecida Giacomini ${ }^{1}$ (it) \\ Verônica Modolo Teixeira ${ }^{1}(\mathbb{D})$ \\ Silvia Helena Henriques ${ }^{1}$ (D) \\ Lucieli Dias Pedreschi Chaves ${ }^{1}$
}

1. Universidade de São Paulo.

Ribeirão Preto, São Paulo, Brasil.
Corresponding author:

Márcia Aparecida Giacomini.

E-mail: marcia.giacomini77@gmail.com

Submitted on $12 / 06 / 2018$.

Accepted on 05/02/2019.

DOI: 10.1590/2177-9465-EAN-2018-0366

\section{Abstract}

Objective: To reflect on activities aimed at the development of graduation students, in a teaching internship program, in the perspective of master's degree and doctoral graduate education and training. Method: It is a reflexive study, based on the discursive formulation about required competencies and guidelines proposed by the National Graduation Plan (named PNPG, Plano Nacional de Pós-Graduação) for professor training articulated to the graduate. Results: The teaching internship program is a way for the formation of university professors, through the preparation of the graduate student. In addition, it shows the relevance of the professor supervisor role in the construction of the learning of these individuals. Conclusion and implications for practice: The first contact with teaching practice, through the teaching internship program, is relevant for constructing a critical look at the teaching-learning process. In this type of Program, it is possible to learn to be and make teaching in a participatory manner, to value interactive relations, to boost autonomy, to stimulate self-evaluation and self-reflection of the graduate student, allowing them to participate actively in the learning process.

Keywords: Professional Practice; Faculty, Nursing; Education, Nursing, Graduate.

\section{Resumo}

Objetivo: Refletir acerca de atividades voltadas para o desenvolvimento de pós-graduandos, em programa de estágio docente na perspectiva de ensino e formação na pós-graduação Stricto sensu. Método: Trata-se de estudo reflexivo, fundamentado na formulação discursiva acerca de competências requeridas e diretrizes propostas pelo Plano Nacional de Pós-Graduação para a capacitação docente articulada à pós-graduação. Resultados: O programa de estágio docente é uma via para a formação de professores universitários por meio do preparo do pós-graduando. Além disso, mostra a relevância do papel docente supervisor na construção da aprendizagem desses indivíduos. Conclusão e implicações para a prática: $O$ primeiro contato com a prática da docência, por meio do programa de estágio docente, mostra-se relevante para a construção do olhar com criticidade do processo de ensino-aprendizagem. Nesse tipo de programa, é possível aprender a ser e a fazer a docência de forma coparticipativa, valorizar as relações interativas, impulsionar a autonomia, estimular a autoavaliação e autorreflexão do pós-graduando, permitindo que participe, ativamente, do processo de aprendizagem.

Palavras-chave: Prática Profissional; Docentes de Enfermagem; Educação de Pós-Graduação em Enfermagem.

\section{Resumen}

Objetivo: Reflexionar sobre las actividades dirigidas al desarrollo de estudiantes de post-graduación en un programa de prácticas de enseñanza, en la perspectiva de stricto sensu graduado de educación y formación. Método: Se trata de un estudio reflexivo, fundamentado en la formulación discursiva acerca de competencias requeridas y directrices propuestas por el Plan Nacional de Postgrado para capacitación docente articulada al posgrado. Resultados: El programa de práctica docente es una vía para la formación de profesores universitarios, a través de la preparación del estudiante de postgrado. Además, muestra la relevancia del papel docente supervisor en la construcción del aprendizaje de estos individuos. Conclusión e implicaciones para la práctica: El primer contacto con la práctica de la docencia, a través del programa de práctica docente, se muestra relevante para la construcción de una mirada con criticidad del proceso enseñanza-aprendizaje. En este tipo de programa es posible aprender a ser y hacer la docencia de forma coparticipativa, valorar relaciones interactivas, impulsar la autonomía, estimular la autoevaluación y autorreflexión del postgrado permitiendo que participen activamente en el proceso de aprendizaje.

Palabras clave: Práctica Profesional; Docente de Enfermería; Educación de Postgrado en Enfermería. 


\section{INTRODUCTION}

\section{Contextualizing the theme}

College Degree Education in Brazil has undergone an accelerated expansion in the last two decades, with an important increase in access, which allowed the continuity of the process of training a large contingent of students from high school. This growth had the incentive of programs for the promotion of College Degree Education, such as the Fund for College Degree Education Students (named FIES, Fundo de Financiamento ao Estudante do Ensino Superior) and the University for All Program (named PROUNI, Programa Universidade para Todos). ${ }^{1}$

With regard to the graduate course, there was an increase in the offer of master's degree and doctoral courses derived, in part, from governmental stimuli through scholarships and, on the other hand, the offer requirements of these courses for the Institution of College Degree Education (named IES, Instituição de Ensino Superior) to reach the status of university. In addition, there was also a significant increase in society's demand for a higher level of schooling, understood as a differential for the labor market. ${ }^{2}$

Master's degree and doctoral graduate courses, in addition to the main objective of scientific research development, constitute a pathway for the formation of university professors, meeting the demand for training of these professionals due Expansion of college degree education. ${ }^{3}$

It is noteworthy that the approach on specific competences for the development of scientific research, in different areas, includes themes that necessarily do not permeate more specific aspects of the competencies required for the practice of Teaching, i.e. master's degree and doctoral graduate courses can form excellent researchers, without having their training and experience of professor training.

The impasse of universities in their attributions, whether in the sense of training for research or pedagogical training for teaching, and also the training of professionals to respond to the demands of the labor market, is not a fact present only in Brazilian scenario. In the USA and Canada, there is already a segmentation of the universities and graduates activities, some focusing on the production of scientific research and others whose scope includes the training of professionals to serve the labor market. This fragmentation is considered to be harmful, since the pedagogical competences for teaching and for research are essential for the exercise of university teaching. ${ }^{4}$

In this sense, it is understood the importance of the interface between training in a specific area and the particularity of professor education, which requires specific references and, because it is a professor's education, it is believed to be pertinent the concept of competence, based in Perrenoud, which is pointed out as an effective way to cope with analogous situations in order to articulate consciousness and cognitive resources with knowledge, capacities, attitudes, information and values, all of this in a fast, creative and connected way. ${ }^{5}$
In the teaching work, one can highlight competences related to the organization of learning situations; to the administration of learning progression; the use of differentiation devices; the involvement of students in their learning and work; focus on teamwork; the use of new technologies; to the confrontation of duties and to the ethical dilemmas of the professor training, the profession and the administration of the own continuous formation. The importance not only of scientific domain, but of pedagogical foundations necessary for good teaching practice, not distanced from practice and respect for ethical-moral commitment, is important in order to meet the needs of the various actors in the educational system. ${ }^{6}$

Given these questions, we need to report to the National Graduation Plan (named PNPG, Plano Nacional de Pósgraduação), which establishes guidelines, strategies and targets for directing actions in this area, among which is the Institutional Professor Training Program (named PIQD, Programa Institucional de Qualificação Docente) for the qualification of the teaching staff in attention to the needs of improvement and expansion of teaching, research and extension activities of Institution of College Degree Education (named IES, Instituições de Ensino Superior) ${ }^{7}$

However, this approach to professor training, coupled with graduation, is not recent in Brazil and in the world, since several teaching institutions adopted different strategies, namely: the insertion of the graduate student in scenarios of university teaching practice in class room, laboratories and/or practical work field. As well as participation in graduate courses with content focused on university and/or college degree education topics, core activities involving the preparation of didactic material, among other strategies, which are succeed by means of programs for the further training of the IES.

In the perspective of professor development, the Coordination of Improvement of Higher Education Personnel (named CAPES, Coordenação de Aperfeiçoamento de Pessoal de Nível Superior) adopted, in 1999, a measure for the improvement of the graduate student focused on professor education, since this may be responsible for College Degree Education in the country, making the teaching internship compulsory, as part of the activities of the masters and doctoral fellows under the supervision of a professor, with a maximum working load of four hours per week, leaving the scholars have the autonomy to organize the format of the said stage, which reinforces the need for their pedagogical training. ${ }^{8}$

Institutions such as the Universidade Federal do Rio de Janeiro (UFRJ), a Universidade Federal de Minas Gerais (UFMG) e a Pontifícia Universidade Católica de São Paulo (PUC-SP) adopt the teaching internship, a compulsory activity for doctorates with the financial assistance of CAPES (Coordenação de Aperfeiçoamento de Pessoal de Nivel Superior), with the possibility of dispensing from the internship those who prove to have developed activity in College Degree Education. 
It is noteworthy that, at the Universidade de São Paulo (USP), even before the standardization of the CAPES (Coordenação de Aperfeiçoamento de Pessoal de Nível Superior), the graduation Dean established the Teaching Improvement Program (named PAE, Programa de Aperfeiçoamento do Ensino) through the provision of monitoring scholarships for graduate students as part of their training. In view of the standardization of the CAPES (Coordenação de Aperfeiçoamento de Pessoal de Nivel Superior), the aforementioned program was regulated by the Ordinance GR 3588 with the objective of contributing to the improvement and training of graduate students enrolled in master's and doctorate levels, in didactic activities of undergraduate teaching, in order to enable a first approximation with political, theoretical and methodological aspects that permeate the teaching and learning actions to be coordinated by them in college degree education institutions. It is understood that, in order to cover the pedagogical and didactic aspects of student training in undergraduate courses, future professors must experience the two stages of the PAE (Programa de Aperfeiçoamento do Ensino) - Pedagogical Preparation and Supervised Internship - that are necessarily articulated and interdependent. ${ }^{9}$

It should enable the student to experience and participate in multiple dimensions of teaching: organizational, which concerns the selection of content, didactic resources, among others; technique, which is related to the monitoring of activities, notes, presence list, among others; pedagogical, linked to the organization and development of classes; professor/student relationship and evaluative dimension. ${ }^{10}$ This stage can only be developed after the pedagogical preparation, being the stage performed in undergraduate disciplines, both theoretical and theoretical-practical. It creates the opportunity to experience, in real context, teaching-learning situations, with different approaches, focuses, scenarios and strategies, together with the supervising professor.

The teaching internship, similar to PAE (Programa de Aperfeiçoamento do Ensino), can have different characteristics. Depending on the structure and the unit in which it applies, the student can participate in disciplines, conferences with specialists in the area of education or core of activities that address topics and issues relevant to college degree education, and the activities must have organizational, technical and didactic-pedagogical approach.

The Masters and doctoral students experience multiple demands inherent to graduation studies, which makes it necessary to recognize that equating time for all activities is a challenge, as well as thinking about the specificity of the preparation for the exercise of teaching, and perhaps, therefore, this last question is relegated in the background. In this direction, questions arise about the insertion of the graduate student in the labor market, specifically in the area of education, which encourages discussing aspects inherent to the academic formalities of teaching internship.
Reflect on the teaching internship appears to be relevant as a possibility to understand the different impact of the performance of professors and doctorates. It is a challenge to equate the various approaches that are embedded in the training of graduate students, since the emphasis of the graduate in Brazil is on the training of researchers, considering the specifics and competences inherent in the training for the production of scientific research. However, due to a contingency, these graduate students become professors of College Degree Education, without necessarily having the pedagogical training required to act in the training of undergraduate students, according to peculiarities inherent to the group of undergraduates themselves, as well as the national scenario of health system. In this sense, in order to overcome the misunderstanding that the scientific competence certified in a Master's degree and Doctoral course is equivalent to the declaration of Pedagogical competence, the experience of the internship in teaching is shown as a potent strategy, even though limited in its workload, to provide the pedagogical development of masters and doctors.

Given the emphasis and specificity of the training of researchers in Master's degree and Doctoral, graduate courses of the challenges of teaching in the contemporary world, the possibility of graduation is a means of professor training, but that necessarily does not encompass desirable pedagogical requirements, the importance of skilled teaching practice and Instrumental to favor the teaching-learning process, of the various technologies and innovations in the teaching available in the current context, of the power created by articulating the look of the graduate student and the supervising professor, providing an opportunity to focus differentiated from activities aimed at the development of graduate students in a teaching internship program, justify the reflection that sometimes presents itself.

This study is expected to contribute to the professor training of the graduate student, as well as to present weighting elements for the supervising professor in a continuous learning process. The objective was to reflect on activities aimed at the development of graduate students, in a teaching internship program, in the perspective of teaching and training in Master's degree and Doctoral graduate studies.

\section{METHOD}

This is a reflexive study, based on the discursive formulation of the required competencies and guidelines proposed by the PNPG (Plano Nacional de Pós-graduação) for professor training articulated with graduate studies, considering the views of graduates and supervisors of a Nursing College Degree Course at a Public Education Institution.

From the context and relevance of the teaching internship to professor training, reflections on pedagogical preparation and the practical internship for teaching were considered, considering the process of meaningful learning. 


\section{RESULTS AND DISCUSSION}

\section{Professor training in the teaching of graduate students}

The formation of the professor for college degree education has a dynamic character; it is built and based not only on pedagogical preparation and in supervised internships in teaching, but also in personal experiences.

The first stage of the teaching internship includes attending specific preparatory discipline, which includes pedagogical approach and contact with specific references on the contents of the discipline program. The graduate student, when identifying and recognizing the issues of College Degree Education in Brazil, different teaching-learning strategies, as well as their facilities and difficulties, can develop skills for teaching practice.

Graduate students, during the insertion in the disciplines, have the possibility to reflect on the professional teaching praxis, besides sharing experiences with other students. The classes with differentiated format, based on different active methods of teaching, favor another approach for College Degree Education. Throughout the classes, the graduate students play the role of professor, by explaining the theme of the class according to the program of the discipline, using active teaching proposals and discussion with other professors on the subject itself, about the performance of the group of graduate students and what could be improved, according to the classes taught, in an actionreflection approach in order to instrumental future action.

It should be pointed out that, in this stage of pedagogical preparation, it is fundamental that the offered course be able to, in fact, qualify the graduate student to the teaching practice, given that each unit or department provides this step according to its Political-pedagogical context, although the objective is common: to fill the existing gaps in professor training.

The supervised internship, developed in theoretical and practical discipline, inserted in a practice scenario, favors meaningful learning, both in terms of structuring and the dynamics adopted for the interaction between the supervising professor, the graduate students.

This experience enables learning about aspects of the organization of the discipline, of professor-student-service relationship and of conducting meaningful learning, in order to bring new meanings to graduate students. One of the reflections that emerge about this theme is about the form of professorstudent communication as a strategy to enhance the teachinglearning process.

In the course of a program aimed at the improvement of future professors, especially in the teaching internship, at various times, the supervising professor has the possibility of providing reflections on the formation of undergraduate students, regarding the strategies of Learning, and the graduation itself can act in this process. Linked to the previous pedagogical preparation, it provides support for the practice and is fundamental for the improvement of teaching, since the teaching-learning process can be understood as something dependent on the valorization of knowledge, stimulation and reflection on the theoretical and the scenario of practice, as well as the co-responsibility of those involved in their own learning.

In the course of the teaching internship, the graduate student also has the opportunity to participate in formative, continuous and shared evaluation processes with the supervising professor and other students, whether in theoretical disciplines and/or in the scenario of professional practice, by means of feedback, supervision, case studies, etc.

In this sense, the graduate student can assume an important role of mediator between undergraduate students and the supervising professor, as it contributes with a critical look at the situations that happen throughout the discipline, both in the perspective of the development of activities the work proposal/ professor approach.

This mediation can trigger relevant reflections, since the graduate student can approach both the professor's and the undergraduate's eyes in an exercise in learning the complexity and multidimensionality of the teaching-learning relationship. It is a relational, communicative and learning process for the three parties involved. However, it is not something simple, since it can bring some movement and/or restlessness in established roles and that is exactly where one of the riches of this experience can be. Finally, depending on established articulations and interactions, this process can constitute an active learning possibility, both for the supervising professor and for the graduate student.

It is understood that teaching, articulated to education and research, is an integrated vision and assumed as an intrinsic pedagogical principle, in which it is perceived that the university essentially needs research, not only for the purpose of generating new knowledge, but to develop qualified education and provide the extension as a way to respond to the demands of society. ${ }^{11}$ In this context, the teaching internship can be understood as a relevant part of the training for graduate student teaching.

Although the proposal for the improvement of the graduate student, focused on professor education, contemplates both stages, the process of professor education is broader, complex, dynamic and lasting. In this sense, there are questions about the feasibility and scope of a specific pedagogical training discipline to fill gaps in professor education, supplying the needs of different courses. ${ }^{3}$ It is understood that it can be a trigger in training, which does not end in graduate school, but should be a continuous process.

The professor acquires attributes to play the role in multiple ways, such as school education and social influences, in addition to continuing education processes, among others, ${ }^{12}$ which extend to the graduate student, as far as professional training is concerned, both in the disciplines of graduate courses focused on didactics and/or College Degree Education as in participation in teaching internship. Nonetheless, it is true that only attending preparatory courses and supervised internships in teaching does not make the graduate professor, i.e.: there is a constant need to update on the specific knowledge to be taught and the 
methods to be used, not to remain in the monotony and play the role of a mere content replicator.

It is essential to understand and know how to take advantage of the changes resulting from globalization in terms of the use of technological resources available to teaching. For the current generation of students, this is an unpostponable process, because existing technologies, when used correctly, can benefit teaching and learning.

The path to be taken by graduate students is meandering and encouraging, and advancing in their training, focusing on the teaching-learning process based on the previous experience of traditional teaching, is a challenge. The adoption of a critical-reflexive attitude towards teaching, the understanding that the professor plays the role of facilitator and stimulator of the intellectual development of the student in the learning process and that the acquisition of knowledge does not, per se, characterize the aptitude for the are advances that require investments to be consolidated.

In order to encourage learning, graduates students and supervisor professors should, in the course of theoretical and practical activities, support undergraduate students, whether in attitudinal or psychosocial and cognitive issues, by stimulating reflection from real situations and to solve doubts, encouraging them to seek the answers of their questions through scientific literature to subsequently discuss the outcome, building a cycle of action-reflection-action.

Through this approach, is stimulated, the formation of more critical and reflexive students, capable of seeking for knowledge and of learning to think in a more articulated way to the context in which they are inserted, understanding the meaning in the work and the potential of the knowledge to qualify practices. Subsequently to all the situations experienced and the activities carried out, it is possible to understand that the journey towards professor training is plural and dynamic.

The stages of the improvement to the teaching practice favor the contact with professional practice, as well as the relationship between theory and practice, with the development of competencies. In addition, they offer graduates students elements to learn how to prepare classes and to use active teaching strategies in the classroom, to reduce the gap between a good theorist and a good professor, to create possibilities for experiencing and exploring the challenges of teaching, as well as evaluating and testing practices in the perspective of teaching, research and extension. ${ }^{3}$

From this perspective, the process by which the graduate student goes through, in the midst of teaching and learning, is arduous and intense, because he is no longer in a student position, but is not yet seen as the professor of the discipline in which he is inserted. Thus, the graduate student goes through periods of deconstruction and construction of his gaze and knowledge in view of the various situations that can be delineating in the daily life of teaching, supervision and learning, a fact that contributes positively to its professor training.

\section{The supervising professor in the construction of learning}

The development of teaching internship can favor the guidance process of the graduate student, by allowing the approximation with the supervising professor, in a perspective of articulation teaching-research not only when it relates to the research theme of the graduation, but also, as a possibility of favoring evidence-based practice, the perception of the relevance of keeping up to date for teaching practice, access to different bibliographic sources, also strengthening the aspect of research consumption and its incorporation into practice that can also raise questions about how to make your own research project viable For potentialized results in this strand.

This is a situation that can mobilize the supervising professor to review and/or seek different pedagogical strategies to discuss the teaching-research articulation and, in this sense, this professor is encouraged to seek new ways/methods to teach pedagogical strategies.

Supervising the graduate student in the teaching internship can be quite enriching for the supervising professor when he understands that he is under different approaches of teachinglearning: that of undergraduate student in his professional training and the graduate student in his teaching training. This double aspect is an unparalleled opportunity to visualize, in an expanded way, the teaching role in College Degree Education, permeated by action-reflection-action and based on scientific and pedagogical knowledge, a situation that may favor the revision of the teaching performance itself, in a process where there can be meaningful learning for all involved.

It is necessary to develop a critical posture in front of the teaching praxis and to enable students to become producers of knowledge and take a critical and reflexive attitude towards the proposed content, enabling them to learn to learn, mainly in their future professional practice.

The use of practice scenarios in student training enables the development of competencies with the necessary clinical reasoning for the exercise of safe professional practice in health. For this, we need not only technical elements, but also organizational and reflective planning, contextualizing the theoretical contents with the problems that emerge from the practice. ${ }^{13}$

The teaching challenge is to stimulate the action-reflectionaction process among the students, to provide opportunities for cognitive development (know-how) and the operational ability (know-how) supported by ethics and commitment (knowing how to be), as well as knowing how to live. In this way, the possibility of changing reality emerges. ${ }^{14}$

It is necessary to think of a greater participation of the graduate students in the preparation of theoretical classes, since they can contribute with new teaching-learning strategies, sharing the learning obtained in the preparatory stage, which would benefit the supervising professor with new knowledge. 
Sharing with the graduate student the practice of teaching in practice scenarios with undergraduate students provides mutual learning, at each meeting with students and professionals of the scenario, favoring the daily reflection on the work itself.

Thus, it is considered that teaching internship is important, both for the graduate student and the supervising professor who, while teaching, have the opportunity to review their own action, in a constant movement of (re)construction, to reinvent in that role to facilitate the teaching-learning process of the graduate student in the walk of teaching. This result is also found in another study ${ }^{15}$ which highlights the relevance of the teaching internship in relation to the process of reconstruction of the meaning of the teaching work, to the reflection about the work of the professor in university education and, in as trainer of trainers. Thus, it presents itself as an aspect capable of favoring the problematic of teaching, in both undergraduate and graduate studies, as well as the construction of new resources for such practice.

\section{FINAL CONSIDERATIONS AND IMPLICATION FOR PRACTICE}

After intense reflection, it is understood that the pedagogical preparation is a fundamental step to be included in the teaching internship, since the participation in theoretical disciplines focused on teaching in College Degree Education enables to understand different active teaching strategies as well as their practical use. Practical activities with nursing undergraduates, accompanied by a supervising professor, with the insertion in the theoretical-practical disciplines of the undergraduate, in the scenarios previously selected, instrument the graduate student for the teaching exercise.

The teaching internship articulates theory and practice, demonstrates the dynamics and problematic of being a professor, through living together with the supervising professor and undergraduate students, enabling the sharing of knowledge among the actors involved, but the relational component can be challenging and compromise the use of this experience. The teaching internship can also provide those involved with reflective, joint and contextualized action to the health service scenario, raising questions in a dynamic teaching-learning relationship that, in addition to professor construction, can promote changes in the environment of theoretical and practical activities of undergraduate students and contribute to an improvement of health services that are practice scenarios.

In the view of the potential of the teaching internship, efforts must be made to create operational conditions conducive to favorable conditions for its development, offering it to graduate students, regardless of whether or not they are scholarship holders, since it allows a problematizing and participative approach that stands out in the construction of professionals in addition to research, developing skills and attitudes, preparing them for teaching.
Given the limitations of the study of the type of reflection, which considers the focus of a specific group of researchers, highlights the contribution in order to allow the construction of multiple views to show the creative potential that experienced processes represent: in relation to graduate students, who when applying the theoretical knowledge acquired in the preparatory discipline, can modify the reality of the context of the theoreticalpractical activities developed and, in relation to the supervisor professor, weights can emerge on the teaching-learning process, leading to improvements in professional practice.

It is believed that this reflection highlights the potential of the teaching internship to be explored, but this is still a challenging, dynamic process, with gaps that must be overcome and better instrumental, emphasizing pedagogical practices that need better and more attention, as well as the appropriation of new technologies, the encouragement to build personal identity and constant renewal of their teaching practices, consistent with social transformations, cultivating criticality and reflection.

\section{REFERENCES}

1. Tachibana TY, Menezes Filho N, Komatsu B. Ensino superior no Brasil. Policy Paper [Internet]. 2015 dec; [cited 2018 sep 05]; 4:1-53. Available from: https://www.insper.edu.br/wp-content/uploads/2018/09/Ensinosuperior-no-Brasil.pdf

2. Cirani CBS, Campanario MA, Silva HHM. A evolução do ensino da pósgraduação senso estrito no Brasil: análise exploratória e proposições para pesquisa. Avaliação (Campinas) [Internet]. 2015 mar; [cited 2018 jan 25]; 20(1):163-87. Available from: http://www.scielo.br/pdf/aval/ v20n1/1414-4077-aval-20-01-00163.pdf

3. Joaquim NF, Vilas Boas AA, Carrieri AP. Estágio docente: Formação profissional, preparação para o ensino ou docência em caráter precário?. Educ Pesqui [Internet]. 2013 abr/jun; [cited 2018 jan 22]; 39(2):351-65. Available from: http://www.scielo.br/pdf/ep/v39n2/ a05v39n2.pdf

4. Tardif M. Questões sobre a docência universitária no Canadá. Entrevistado por Silvia Maria Nóbrega-Therrien. Traduzido do francês por Rosa dos Anjos Oliveira. Em Aberto, Brasília. 2016 set/dez; [acesso em 2019 mar 29]; 29(97):133-140. Disponível em: http://www.emaberto. inep.gov.br/index.php/emaberto/article/view/2953/2675

5. Perrenoud P. Construir competências é virar as costas aos saberes? Pátio Rev Pedagógica [Internet]. 1999 nov; [cited 2018 oct 15]; 3(11):15-9. Available from: http://egov.ufsc.br/portal/sites/default/files/ anexos/29108-29126-1-PB.pdf

6. Perrenoud P. Dez novas competências para ensinar. Porto Alegre: Artmed Editora; 2000.

7. Ministério da Educação (BR). Coordenação de Aperfeiçoamento de Pessoal de Nível Superior - CAPES. Plano Nacional de Pós-Graduação - (PNPG) 2005-2010 [Internet]. Brasília: Ministério da Educação. 2004 dez; [cited 2018 jun 15]. Available from: http://www.capes.gov.br/ images/stories/download/editais/PNPG_2005_2010.pdf

8. Ministério da Educação (BR). Circular $n^{\circ} 28$, de $1^{\circ}$ de setembro de 1999. Estabelece requisitos para concessão de bolsas. Diário Oficial da União, Brasília (DF), 12 nov 1999.

9. Universidade de São Paulo - USP. Pró-Reitoria de Pós-Graduação. Programa de Aperfeiçoamento de Ensino - PAE. Diretrizes para a proposição das Disciplinas da Etapa de Preparação Pedagógica [Internet]. São Paulo: Universidade de São Paulo. 2017; [cited 2019 feb 12]. Available from: http://www.prpg.usp.br/attachments/article/631/ Diretrizes\%20para\%20disciplina\%20de\%20EPP\%20-\%2029-092016.pdf 
10. Universidade de São Paulo - USP. Pró-Reitoria de Pós-Graduação. Programa de Aperfeiçoamento de Ensino - PAE. Diretrizes [Internet]. São Paulo: Universidade de São Paulo. 2010; [cited 2018 jan 17]. Available from: http://www.prpg.usp.br/attachments/article/631/Diretrizes_PAE.pdf

11. Severino AJ. Da docência no ensino superior: condições e exigências. Comunicações [Internet]. 2013 jan/jun; [cited 2018 jan 15]; 20(1):4352. Available from: http://sites.uepg.br/prograd/wp-content/themes/ PROGRAD/assetsDes/artigos/Artigo\%20Severino.pdf

12. Iza DFV, Benites LC, Sanches Neto L, Cyrino M, Ananias EV, Arnosti RP, et al. Identidade docente: as várias faces da constituição do ser professor. Rev Eletr Educ [Internet]. 2014; [cited 2018 oct 12]; 8(2):27392. Available from: http://dx.doi.org/10.14244/198271999978
13. Florêncio PCS, Austrilino L, Medeiros ML. O processo ensino aprendizagem nos cenários de prática; concepções dos docentes do curso de graduação em enfermagem. ATAS CIAIQ [Internet]. 2016 jul; [cited 2018 nov 15]; 2(2016):1312-9. Available from: https://proceedings. ciaiq.org/index.php/ciaiq2016/issue/view/13

14. Chamlian HC. Docência na universidade: professores inovadores na USP. Cad Pesqui [Internet]. 2003 mar; [cited 2017 nov 25]; 118:41-64. Available from: http://www.scielo.br/pdf/cp/n118/16829.pdf

15. Kramer S, Souza MC, Oliveira A. Estágio de docência e metodologia de ensino de língua portuguesa: literatura como caminho para a formação. Leitura: Teoria \& Prática [Internet]. 2015; [cited 2018 nov 12]; 33(64):6580. Available from: https://tp.emnuvens.com.br/ttp/article/view/369/270 